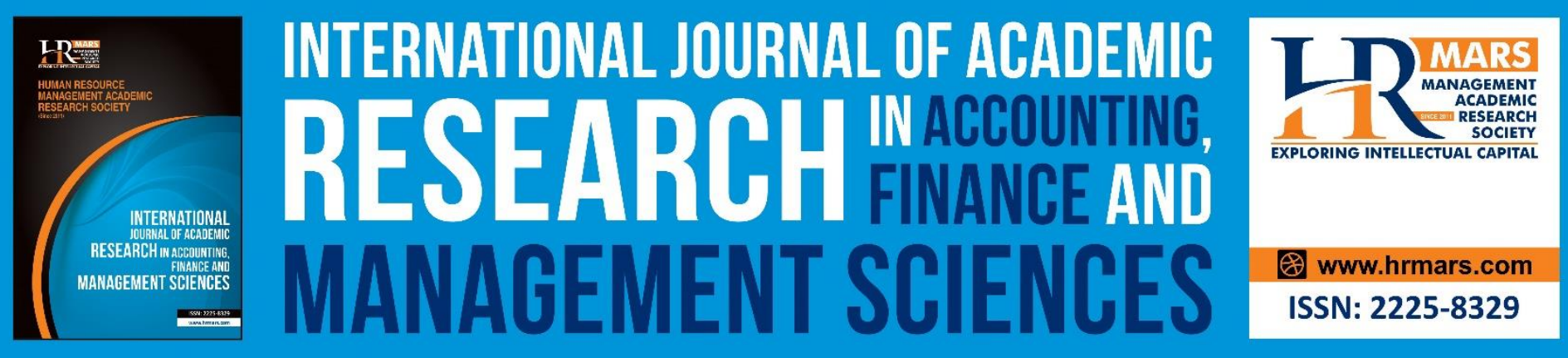

\title{
Impact of Indebtedness on Financial Performance of Quoted Downstream Oil and Gas Companies in Nigeria.
}

\section{Solanke Abiola Abosede}

To Link this Article: http://dx.doi.org/10.6007/IJARAFMS/v10-i4/8450

DOI:10.6007/IJARAFMS /v10-i4/8450

Received: 11 November 2020, Revised: 04 December 2020, Accepted: 29 December 2020

Published Online: 16 January 2021

In-Text Citation: (Abosede, 2020)

To Cite this Article: Abosede, S. A. (2020). Impact of Indebtedness on Financial Performance of Quoted Downstream Oil and Gas Companies in Nigeria. International Journal of Academic Research in Accounting Finance and Management Sciences, 10(4), 8-21.

Copyright: (C) 2021 The Author(s)

Published by Human Resource Management Academic Research Society (www.hrmars.com)

This article is published under the Creative Commons Attribution (CC BY 4.0) license. Anyone may reproduce, distribute, translate and create derivative works of this article (for both commercial and non-commercial purposes), subject to full attribution to the original publication and authors. The full terms of this license may be seen at: http://creativecommons.org/licences/by/4.0/legalcode

Vol. 10, No. 4, 2021, Pg. 8 - 21

Full Terms \& Conditions of access and use can be found at http://hrmars.com/index.php/pages/detail/publication-ethics 


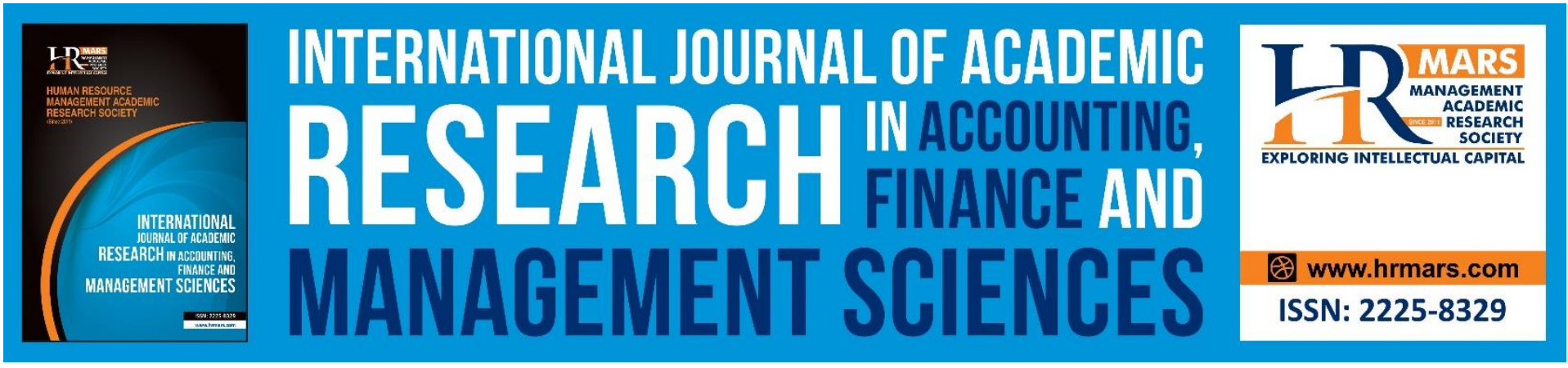

\title{
Impact of Indebtedness on Financial Performance of Quoted Downstream Oil and Gas Companies in Nigeria.
}

\author{
Solanke Abiola Abosede \\ Department of Accountancy, The Federal Polytechnic, Bida, Nigeria \\ Email: mosunmolal1974@gmail.com
}

\begin{abstract}
This study examines the impact of indebtedness on the performance of quoted Nigerian downstream oil and gas companies. The main objective of the study is to find out whether or not indebtedness has impact on the financial performance of the quoted Nigerian downstream oil and gas companies, using Return on asset (ROA) and Return on capital employee (ROCE) as proxies to financial performance. Secondary data of 11 listed oil and gas companies on the Nigeria Stock Exchange from 2007-2019 were used in the study. The data generated were analyzed using multiple regressions to examine the relationship between the variables. Indebtedness is proxied by long term debt, short term debt and total debt, using the pooled ordinary least square, fixed effect and random effect models. After the estimation, the study found that long term debt negatively and significantly impact on the financial performance of quoted Nigerian downstream oil and gas companies. The study recommends that listed downstream oil and gas firms in Nigeria should make effective use of long term debts to enhance their capital employed with a view to generating more return on investment to cover cost of capital and increase their retained earnings.

Keywords: Indebtedness, Financial Performance, Return on Assets, Firms Attribute, Downstream Oil \& Gas Firm

\section{Introduction}

The relationship between indebtedness and firm's financial performance is one of the blue print issues in corporate financial literatures. As business performance of any firm today's globalizing world represent an indicators of how successful and competitive a company is being measured. Firms performance should continually be measure in order to keep the company in a going concern position in current and future time as well (Lenka, 2017). Indebtedness refers to the way the firms finance its assets. Its represent the long term, short term and total debt located at the left hand side of the balance sheet which is the liability plus equity of the company (Ravindra \& Rao, 2014).
\end{abstract}


It can also be defined as the extent to which a firm or investor is using the borrowed money to finance their business, being it long term shot term or total debt. According to (Joseph, 2018), is a measure of how much firms uses equity and debt to finance its asset. Scholars believe debt financing is better to internal financing because of the tax advantages associated with it (Nwaolisa \& Chijinde, 2016). Which is refers to as tax shield (Abubakar \& Garba, 2019). Debt is one of the sources of financing long term activities of firm that largely determines its performance (Nwude, Itiri, Abgadua \& Udeh, 2016; Prempeh, Sekyere \& Asare, 2016). The major issues or challenges with indebtedness are the agreement that the firm have to pay back the debt as well as the interest charges and this subjecting the firm to financial bankruptcy or distress (Nwaolisa \& Chinjindu, 2016). Since proportion of its cash flow must be dedicated to debt servicing (Jeleel \& Olayiwola, 2017).

Over-indebtedness represents a principle of social exclusion that can lead to loss of reputation, humiliation, and in extreme cases, into suicide (Schicks 2014). The more firm is indebtedness, the more financial leverage it employees. (Kenn-Ndubuisi \& Nweke, 2019) external sources can be used as one of the major tools used by a firm to improve performance. The external sources according to (Ken-Ndubuisi \& Oyema, 2018) is a key in acceleration of firms growth, as its permits the firms to leverage on existing fund towards achieving its target growth or objective. Thus, different firms use different sources of capital to finance the activities of the firm. (MacCarthy \& Ahulu, 2019) firms with a lower percentage of debt are likely to perform better in relation to financial performance.

This means the higher the debt the lower the profit, as the profit will be used to finance the debts. (Mutai, 2014) the increase in the ratio of indebtedness irrespective of the type and the sources of debt greatly affect the image of the firm. The quoted downstream Nigeria oil and gas industry play a vital role in the Nigeria economy. Oil was discovered in 1956 in Nigeria with subsequent collapse in agricultural production, the economy sustainability now depends on crude oil in Nigeria. Nwaolisa \& Chjindu, (2016) as conflicting result exist between indebtedness and profitability of oil and gas industry in Nigeria. Oladejo, Tolulope, Ikpetan \& Olokoyo, (2015) analyse the impact of capital structure on firm performance in Nigeria from 2003-2012, the study utilized secondary data from the annual report of six selected petroleum companies in Nigeria, using return on asset, leverage, firm size, Tax and year effect as the study variables and found a negative link between leverage and firms performance, and found positive relationship between firm performance and three explanatory variables on the other hand in Nigeria petroleum industry.

Oke \& Obalade, (2015) confirmed a static trade-off theory which stated that highly profitable firms uses more debt to finance the business operation because of the little risk attached to bankruptcy with the believe that tax shield will be substantial for the firm in terms of financing. Nwaolisa \& Chijindu, (2017) use return on asset, return on equity, debt to equity and earnings per share to proxies financial performance of the companies from 1993-2013 were the study found negative influence on profitability of oil and gas firms. The findings however, contradict the result of Coke \& 'Obalade, (2015) which found that big firm with more tangible assets would use more debt to fiancé their business. Akparhuere, Eze \& Unah, (2015) study the effect of capital structure on retained earnings in the oil and gas sector, were it was revealed that retains earnings positively affect determined borrowing while share capital positively and strongly determines 
INTERNATIONAL JOURNAL OF ACADEMIC RESEARCH IN ACCOUNTING, FINANCE AND MANAGEMENT SCIENCES

Vol. 10, No. 4, 2021, E-ISSN: 2225-8329 ๔ 2021 HRMARS

retains earnings and the study concluded borrowing should be increase so as to increase retains earnings.

Studies in Nigeria and else were have identified several predictors of financial performance, Klimenok, 2014; Oladeji, Tolulope, Ikpefan \& Olokoyo, 2015; Akpahuere, eze \& Unah, 2015; Oke\& Obalade, 2015; Nwaolisa \& Chijindu, 2016; some of the identified predictors are Return on asset, Tax, Earnings per share, Retains earnings, profitability, Age, Tangibility. However, the relationship between indebtedness and firms performance in the downstream oil and gas industry has not yet been irrefutably recognized as study on indebtedness influence on firm's performance with special reference to downstream oil and gas industry in Nigeria are minimal, more so, the scope of the variables analyses in the study needs to be updated.

Coupled with the non-availability of the companies analyzed on Nigeria stock exchange, this has limited adequate understanding of the influence indebtedness on financial performance of oil and gas companies in Nigeria. To this effect, this study focused attention on the general implication of indebtedness on firm performance that has undermined empirical evidence of the underlying association between indebtedness and firm's financial performance of the oil and gas industries. Hence the objective of this study is to examine the relationship between financial performance and indebtedness, the scope of the study covers the period from 2007 to 2019.

\section{Literature Review}

Mohammed \& Hassan, (2015) investigated the impact of financing and evaluating the performance of companies in relation to debt and the optimal structure of debt. Finding revealed negative and significant relationship between financing through debt and performance, the result further revealed financing company with short or long term debt has a negative impact on firm's performance. The study recommended that investor should considered financing structure at the time of decision making when doing their analyses.

Prempeh, Sekyere \& Asare, (2016) found that short term, long term and total debt has negative effect on firms performance, implication of this finding showed that firms uses more of debt to acquire asset which can easily be jeopardized in continually using more of debt to finance their operational activities. Furthermore, Nwaolisa \& Chinjindu (2016), using ordinary least square (OLS) regression techniques, maintained that return on asset, return on equity, profit before tax and earnings per share are negatively associated with financial structure profitability of oil and gas firms. This finding implies that oil and gas firms in Nigeria use more of equity and debt in their operational activities.

Mwangi, Willy \& Patrick (2016), concluded in their study that financial structure affect the financial performance of the firms listed on the East Africa Securities exchange directly or indirectly. Nwude, Itiri, Agbadua \& Udeh (2016), observed in their research that debt structure has negative and significant impact on the performance of Nigeria quoted firms in the study period. This implies that manufacturing firms listed on Ghana stock exchange uses about $95 \%$ of debt to fund their operational activities. This finding support the work of Jeleel \& Olayiwola (2017) who earlier related that firms leverage of listed chemical and paint firms in Nigeria mainly use debt in financing their business.

The finding is further buttressed by Ikapel \& Kajirwa (2017) who also argued that firms that use long term debt in their capital structure is likely to go into bankruptcy because proportion of long term debt negatively affects firms financial performance and concluded firms should manage 
INTERNATIONAL JOURNAL OF ACADEMIC RESEARCH IN ACCOUNTING, FINANCE AND MANAGEMENT SCIENCES

Vol. 10, No. 4, 2021, E-ISSN: 2225-8329 @ 2021 HRMARS

well the portfolio of its long term debt structure to minimize risk associated to long term debt. Harelimana (2017) conducted a study to finds out the effect of using debt to finance business, comparing the analyses between two banks in Kigali Rwanda using comparative descriptive and correlative research design to achieve the stated objective. It was found that the level of debt positively impact on firm profitability of both banks after adding control variables to the analyses. The implication of this result showed that, there is a significant positive relationship between debt level and financial performance which indicated that, performance in terms of profitability, sustainability and liquidity has improved gradually.

Lenka (20170 investigated the relationship between business competitiveness using leverage and corporate performance. The study found significant negative effect on corporate performance using return on equity as indicators of corporate performance. The regression analyses further revealed negative relationship between the company profitability and use of debt in financing the business operation. Ken-Ndubuisi, Ifechi \& Onyema (2018) carried out a study between financial leverage and asset growth. The regression analysis indicate a significant negative relationship between leverage and asset growth, indicating that investing with leverage has negative influence on the asset growth of the firm.

Joseph (2018) studies the effect of financial leverage on firm performance. The study revealed most businessmen in developed and developing country as well as limited liability companies preferred to run their business with their personal funds; donations, from family members and share capital respectively. The finding therefore revealed a mixed result. Omollo, Muturi, \& Wanjare (2018) analyses the effects of debt indicators namely short term, long-term and total debt on firm financial performance using return on asset and return on equity as measurement of variables. The study empirically revealed that short-term, long-term and total debt negatively and significantly influence return on equity across all the used methods. This mixed result is in line with the study of Josehp (2018).

Gadzo \& Asiamah (2018) found a negative relationship between the level of leverage and return on asset and positive relationship between return on equity and level of leverage of unlisted banks in Ghana. This result implies that any slight increase in leverage automatically lead to decrease on return on asset. The study recommended that bank industry in Ghana should strife as much as possible to develop policies that will inject more funds in the banking operational activities.

Pandey \& Sahu (2019), documented impact of debt financing on firms performance using two different types of panel data estimation from 2009-2016. Result revealed positive effect between agency cost and firm performance while positive impact was also found between firms performance and return on equity. This findings implies there will be a reduction of clashes of interest existing between the managers and owners of the firm to an extent because its allows managers act in the best interest of their principal.

Gichuru, Kung'u \& Gakobo (2019) established the impact of capital structure on profitability of government based deposit taking, saving and credit co-operatives in Kenya. Result revealed negative result in all the used variables, though the result was insignificant in relation to the firm's profitability. It was concluded by the researcher that mix of equity and debt that will minimize membership returns and wealth should be maintained in the firm.

MacCarthy \& Ahulu (2019) examined whether capital structure affects firms performance in Ghana using panel data of listed firms on Ghana stock exchange from 2009-2018. The result 
showed a significant and negative effect between capital structure and firms performance. The study concluded firms should use equity capital to finance their operations that concentrating on the use of debt capital. Implication of this showed that every increase in debt financing lead to decrease on return on equity of the firm.

Kenn-Ndubisi, Ifechi \& Nweke (2019) empirically examine the effect of financial leverage on selected indicators of firm performance in Nigeria using total debt to capital ratio, debt to equity ratio as a proxy for financial leverage using pooled regression model, fixed effect model, random effect model and marginal model. Findings showed mixed result among the variables used in relations to negative and positive. The implication of this study finding is that some of the variables use does not have significant impact on the firm financial performance while some have negative influence on the performance financially.

Zaidi, Jais \& Karim (2019) investigated the influence of debt financing on firms performance of consumer product industry in Malaysia for a period from 2001-2015. The finding revealed significant relationship between short and long term debt while insignificant relationship was found between account payable and firm size. The study concluded among others that size of the firm does not really matter on performance of the firms financially because it has no any effect on the firm profitability. This study is not different from the work of Chang, Batmunkh, Wong \& Jargalsaikhan (2019) were negative association was also found between growth and leverage of the firm in Taiwan, Korea and Hongkang. Abubakar \& Garba (2019) studied the relationship between financial leverage and financial performance of quoted service firms in Nigeria. The result revealed a negative relationship between short term, debt ratio, long term, and total debt to equity. Which means any increase on the variable also trigger the interest payment?

Igbinovia \& Ogbeide (2019) assesses the relationship between capital structure and firm value of the selected quoted manufacturing companies in Nigeria using the ordinary least square (OLS) on a sample of fifteen selected firm from 2012 to 2017. The study concluded that leverage, tangibility, profitability and age of the firm negatively and significantly impact firm values statistically. Therefore, firms in the sector should reduce their source of capital structure in relation to debt to finance their firm operational activities in other to avoid more debt Oladeji, Tolulope, Ikpefan \& Olokoye (2015) empirically analyses the impact of capital structure on firm performance in Nigeria from 2003- 2012 using secondary data of six petroleum companies. The fixed effect estimation result revealed negative relationship between leverage and firm performance. The study concluded among others that industry should desist from relying on the use of more equity to finance their business

Apkarhuere, Eze \& Unah (2015) found positive relationship between capital structure and retain earnings in their study effect of capital structure on retained earnings in oil and gas sector. Oke \& Obalade (2015) carried out a study title Testing the validity of optimal capital structure theory in Nigeria listed oil and firms industry, were it was found that highly profitable firms uses more debt to fiancé their business because of the tax shield advantages and the little risk of bankruptcy that will be involved. These implied that Tax shield has a higher advantage in relation to interest attached to paying back period to the extent that low risk of bankruptcy will be experienced Cole, Yan \& Hemley (2015) explored the relationship between capital structure and firm performance. Findings of the result revealed capital structure positive impacts return on asset and operating margin in the entire three sectors studied. The study concluded healthcare 


\section{INTERNATIONAL JOURNAL OF ACADEMIC RESEARCH IN ACCOUNTING, FINANCE AND MANAGEMENT SCIENCES \\ Vol. 10, No. 4, 2021, E-ISSN: 2225-8329 @ 2021 HRMARS}

industry should use debt to finance their business and seek alternative financing option in the energy sector were negative impact was found in relation to firms performance.

Conceptual frame work is use in this study to describe the relationship between indebtedness and financial performance as found in the theories. These associations are summarized below as figure 1 indebtedness and its determinants

Figure 1:

\section{Conceptual Framework}

Indebtedness

Firms financial performance

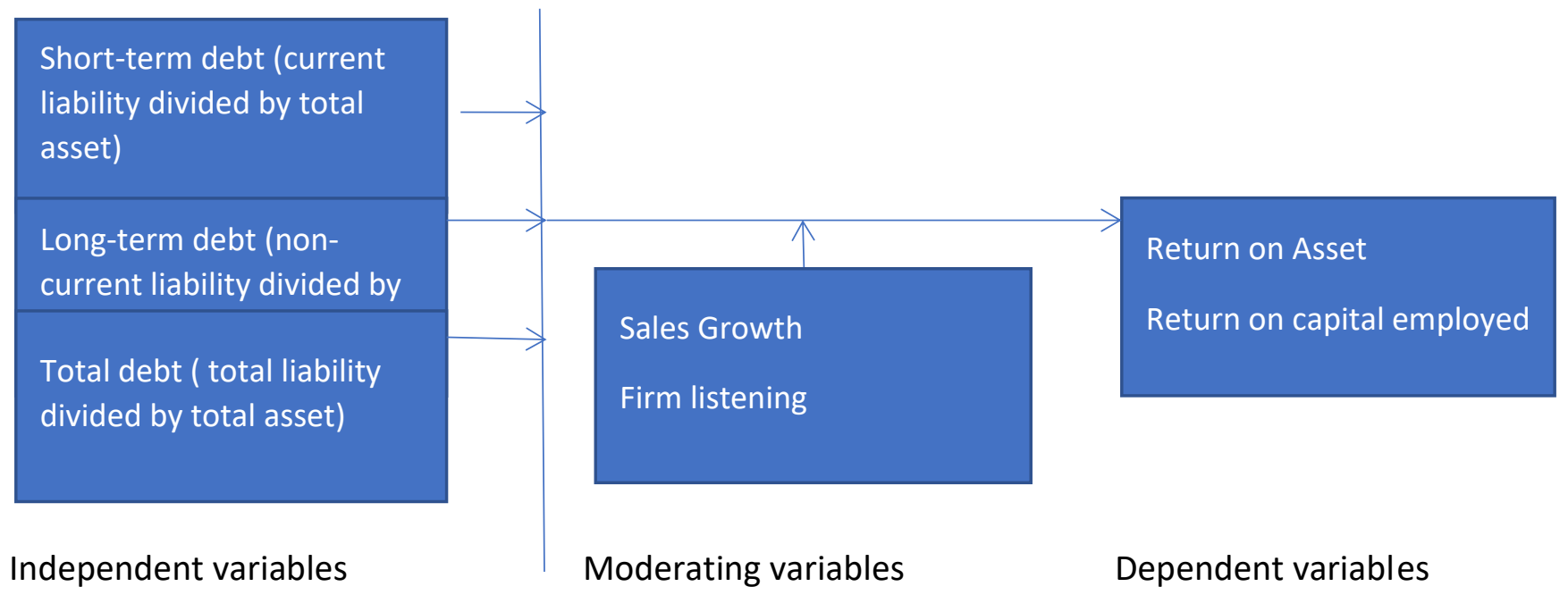

\section{Theoretical Frame Work}

Trade-off theory provided a means of explaining that firm should select an optimal debt that that maximizes the firm's value by minimizing cost of prevailing market imperfection (Shaikh \& Wang, 2010). The trade-off theory stated that those firms with higher level of retained earnings tend to have higher debt levels because they can effectively take advantage of tax shields on interest (Abubakar, 2017). An optimal capital structure is achieved when the marginal present value of tax shield on additional debt is equal to the marginal present value of the costs of financial distress on additional debt (Abubakar \& Garba, 2019). This study adopts the Trade-Off Theory as its theoretical framework; were by the study depicts the relationship between indebtedness and firms financial performance.

\section{Methodology}

This study adopted explanatory research design using secondary data of annual reports of 11 listed oil and gas firms listed on the Nigeria stock exchange as at 2019 to find out the relationship between indebtedness and firms financial performance from 2007-2019. Data was analyses using correlation, descriptive statistics and multiple regressions. The sample size for the study was all the listed oil and gas firm on the Nigeria stock exchange that have data available as at 2019. The proxies that were used to measure independent variables were short-term, long-term and total debt. Proxies for financial performance of the firm are Return on asset and return on capital employed. The regression analyses were used to measure the relationship between Return on 
INTERNATIONAL JOURNAL OF ACADEMIC RESEARCH IN ACCOUNTING, FINANCE AND

MANAGEMENT SCIENCES

Vol. 10, No. 4, 2021, E-ISSN: 2225-8329 @ 2021 HRMARS

asset, Return on capital employed and the moderating variables. The analyses was done using

Stata 12 version 13 software

\section{Model Specification}

To achieve the stated objective of the study, as well as testing the study hypotheses, the multiple regression models was specified as follow

Where $\mathrm{Y}=R O A$ or $R O C E$

Where $Y: \quad S T D=$ Short-term debt

$L T D=$ Long-term debt

$T D=$ Total debt

$S G=$ Sales Growth

$F L=$ Firm listening

$\mathrm{Y}=a+\beta_{1}(\mathrm{STD})+\beta_{2}(\mathrm{LTD})+\beta_{3}$ (TD)

Without control variables

$\mathrm{Y}=a+\beta_{1}(\mathrm{STD})+\beta_{2}(\mathrm{LTD})+\beta_{3}(\mathrm{TD})+\beta_{3}(\mathrm{SG})+\beta_{4}(\mathrm{FL})$

With control variables

\section{Normality Test}

Normality test was conducted for ROCE, and ROA using skewness and kurtosis. The results revealed that the data are normally distributed. None of the probability values are significant reflecting the fact that data are normally distributed

Table 1: Normality Test using Skewness/Kurtosis

\begin{tabular}{|l|l|l|l|l|l|}
\hline Variable & Obs & Pr(Skewness) & Pr(Kurtosis & Adj chi2(2) & prob>chi2 \\
\hline $\begin{array}{l}\text { Return on capital } \\
\text { employee }\end{array}$ & 110 & 0.0000 & 0.0000 & 54.65 & 0.0000 \\
\hline Return on asset & 110 & 0.0000 & 0.0000 & 62.70 & 0.0000 \\
\hline
\end{tabular}

Table 2: Descriptive Characteristics of the Variables

\begin{tabular}{|l|c|l|}
\hline Variable & Mean & SD \\
\hline Return on capital employed & .824454 & 11.94767 \\
\hline Total debt & $\mathbf{8 0 . 5 7 8 9 1}$ & 72.04527 \\
\hline Long term debt & $\mathbf{. 2 1 4 4 5 4 5}$ & .2875923 \\
\hline Short term debt & .591 & .7241014 \\
\hline Sales growth & $\mathbf{5 5 . 3}$ & 35.6212 \\
\hline Firm listening & $\mathbf{2 6 . 3}$ & 11.64187 \\
\hline
\end{tabular}

Source; Authors computation 
INTERNATIONAL JOURNAL OF ACADEMIC RESEARCH IN ACCOUNTING, FINANCE AND MANAGEMENT SCIENCES

Vol. 10, No. 4, 2021, E-ISSN: 2225-8329 @ 2021 HRMARS

Table 3: correlation Matrix between the independent variable and Return on capital employed

\begin{tabular}{|l|l|l|l|l|l|l|}
\hline Variables & $\begin{array}{l}\text { Return on } \\
\text { asset }\end{array}$ & Total debt & $\begin{array}{l}\text { Long time } \\
\text { debt }\end{array}$ & $\begin{array}{l}\text { Short } \\
\text { time } \\
\text { debt }\end{array}$ & $\begin{array}{l}\text { Sales } \\
\text { growth }\end{array}$ & $\begin{array}{l}\text { Firm } \\
\text { listing }\end{array}$ \\
\hline $\begin{array}{l}\text { Return on capital } \\
\text { employee }\end{array}$ & 1.0000 & & & & & \\
\hline Total debt & -0.0932 & 1.0000 & & & & \\
\hline p-value & 0.3329 & & & & & \\
\hline Long term debt & -0.4222 & 0.1870 & 1.0000 & & & \\
\hline p-value & 0.0000 & 0.0505 & & & & \\
\hline Short term debt & 0.0753 & 0.9207 & -0.2113 & 1.0000 & & \\
\hline p-value & 0.4344 & 0.0000 & 0.0267 & & & \\
\hline Sales growth & 0.2702 & -0.1107 & -0.0926 & -0.0730 & 1.0000 & \\
\hline p-value & 0.0043 & 0.2495 & 0.3360 & 0.4488 & & \\
\hline Firm listening age & 0.3158 & 0.0297 & -0.2658 & 0.1351 & -0.1046 & 1.0000 \\
\hline$p$-value & 0.0008 & 0.7579 & 0.0050 & 0.1595 & 0.2767 & \\
\hline
\end{tabular}

Source; Authors computation

Table: 3

Table one presents the relationship between long term, short term, total debts, sales growth, firm listening and return on capital employed. With respect to the relationship between total debt and ROCE, the $r$ value is -0.0932 which signifies a negative and weak correlation between total debt and ROCE. Similar pattern was observed for the relationship between long term and short term debts, the $r$ value of -0.4222 showed a negative correlation between long term and ROCE. On the other hand, the relationship between short term debt, sales growth, and firm listing are all positively related to ROCE. The $r$ value for the relationship between short term debt and ROCE is 0.0753 , sales growth is 0.2703 and firm listing is 0.3158 .

Table 4: regression analysis showing influence on debt on return on asset

\begin{tabular}{|l|l|l|l|ll|}
\hline Return on capital employee & Coefficient & $\mathbf{T}$ & p-value & \multicolumn{2}{|c|}{ 95\% Confidence Interval } \\
\hline Long time debt & -13.68644 & -3.86 & 0.000 & -20.72467 & -6.648207 \\
\hline Sales growth & .1006981 & 3.32 & 0.002 & .0386473 & .1627488 \\
\hline Firm listening age & .2628553 & 2.99 & 0.003 & .0887795 & .4369311 \\
\hline Constant & -8.722124 & -2.49 & 0.014 & -15.65762 & -1.786632 \\
\hline
\end{tabular}

$\mathrm{F}=14.57 ; \quad \mathrm{p}$-value $<0.05 ; \quad \mathrm{R}$-square $=0.29$

Multiple regression was conducted to examine the relationship between independent variables(long term debt, sales growth and firm listing) the multiple regression with three predictions (long term debt, sales growth, firm listing) produced $r^{2}=0.29, F=0.14 .57, p$-value $<0.05$. Long term debt as one of the predictor had negative and significant regression weight, sales growth and firm listing had positive and significant regression ( 0.1006 and 0.2628$)$. The coefficient of determination $\left(r^{2}\right)$ value is 0.29 implies that the explanatory variables accounted for $29 \%$ variation in the ROCE. 
INTERNATIONAL JOURNAL OF ACADEMIC RESEARCH IN ACCOUNTING, FINANCE AND MANAGEMENT SCIENCES

Vol. 10, No. 4, 2021, E-ISSN: 2225-8329 @ 2021 HRMARS

Table 3: Correlation Matrix showing relationship between debt variables and return on asset

\begin{tabular}{|l|l|l|l|l|l|l|}
\hline Variables & $\begin{array}{l}\text { Return on } \\
\text { asset }\end{array}$ & $\begin{array}{l}\text { Total } \\
\text { debt }\end{array}$ & $\begin{array}{l}\text { Long time } \\
\text { debt }\end{array}$ & $\begin{array}{l}\text { Short time } \\
\text { debt }\end{array}$ & $\begin{array}{l}\text { Sales } \\
\text { growth }\end{array}$ & $\begin{array}{l}\text { Firm listing } \\
\text { age }\end{array}$ \\
\hline $\begin{array}{l}\text { Return on } \\
\text { asset }\end{array}$ & 1.0000 & & & & \\
\hline Total debt & -0.0237 & 1.0000 & & & & \\
\hline p-value & 0.8059 & & & & & \\
\hline $\begin{array}{l}\text { Long time } \\
\text { debt }\end{array}$ & -0.3950 & 0.1870 & 1.0000 & & & \\
\hline p-value & 0.0000 & 0.0505 & & & & \\
\hline $\begin{array}{l}\text { Short term } \\
\text { debt }\end{array}$ & 0.1808 & 0.09207 & -0.2113 & 1.0000 & & \\
\hline p-value & 0.0588 & 0.0000 & 0.0267 & & & \\
\hline Sales growth & 0.2497 & -0.1107 & -0.0926 & -0.0730 & 1.0000 & \\
\hline p-vale & 0.0085 & 0.2495 & 0.3360 & 0.4488 & & \\
\hline $\begin{array}{l}\text { Firm listing } \\
\text { age }\end{array}$ & 0.3164 & 0.0297 & -0.2658 & 0.1351 & -0.1046 & 1.0000 \\
\hline p-value & 0.0008 & 0.7579 & 0.0050 & 0.1595 & 0.2767 & \\
\hline
\end{tabular}

\section{Source; Authors computation}

Table 4 presented the relationship between the independent variables (long term debt, short term debt, total debt, sales growth, firm listing and return on asset) with respect to the relationship between total debt and return on asset, the $r$-value is -0.0237 this signifies a weak correlation between total debt and return on asset. Similar pattern was observed for the relationship between long term debt and short term debt. The value -0.3950 showed a negative correlation between long term debt and return on asset. On the other hand, the relationship between short term debt, sales growth and firm listing are all positively related to return on asset. The $r$ - value between short term debt and return on asset is 0.1808 , sales growth 0.2497 and firm listing 0.3164 .

Table 4: Regression on Return on asset

\begin{tabular}{|l|l|l|l|l|}
\hline Return on asset & Coefficient & $\mathbf{T}$ & $\mathbf{p}$-value & $\begin{array}{l}\text { 95\% Confidence } \\
\text { Interval }\end{array}$ \\
\hline Long term debt & -13.54025 & -3.47 & 0.001 & $-21.27615-804353$ \\
\hline Sales growth & .1015233 & 2.95 & 0.004 & .0333218 .1697249 \\
\hline Firm listening age & .2900995 & 3.01 & 0.003 & .0987684 .4814306 \\
\hline Constant & -9.332271 & -2.43 & 0.017 & $-16.95525-1.709296$ \\
\hline
\end{tabular}

$\mathrm{F}=12.71 ; \quad \mathrm{p}$-value $=0.05 ; \quad$ R-square $=0.26$

Table 4

Multiple regressions were conducted to finds out the relationship between the independent variables (long term debt, short term debt, total debt, sales growth and firm listing). The multiple regression with 3 predictors (long term debt, sales growth and firm listing) produce $r^{2}=0.26, F=$ 12.71, $p$-value $<0.05$. Long term debt as one of the predictor heard negative and significant 
INTERNATIONAL JOURNAL OF ACADEMIC RESEARCH IN ACCOUNTING, FINANCE AND

MANAGEMENT SCIENCES

Vol. 10, No. 4, 2021, E-ISSN: 2225-8329 @ 2021 HRMARS

regression weight, sales growth and firm listing hard positive and significant regression. (.10152 and .2900) the $r^{2}$ value which is 0.26 implies that independent variables (long term debt, short term debt, total debt, sales growth and firm listing) accounted for $26 \%$ of variation on the return on asset.

\section{Discussion of Findings}

This study examines the relationship between indebtedness and firm's financial performance of oil and gas firms in Nigeria. From the result from table 3, 4, and 5 respectively, the performance of oil and gas firm's variables which were measured with ROCE and ROA demonstrated a statistically negative relationship with all the indebtedness indicators which were measure with LTD, STD, and TD. The outcome of the study implied that, the performance of the firms will increase in terms of sales, but decrease in profit because of the paying back interest as firm sources of capital is from outside borrowing. Again, from the trade-off theory perspectives, there is a relationship between the debt provider and the firm, such that the firms are to utilized the borrowed funds effectively in other to increase their cash flow and be able to meet up with the paying back period with the interest. From the empirical review, quite a numbers of study have concluded on the effect of debt on financial performance of firms, such as

Klimenok, 2014; Oladeji, Tolulope, Ikpefan \& Olokoyo, 2015; Akpahuere, eze \& Unah, 2015; Oke\& Obalade, 2015; Nwaolisa \& Chijindu, 2016; some of the identified predictors are Return on asset, Tax, Earnings per share, Retains earnings, profitability, Age, Tangibility. Although, the year of previous studies differs for the study, the methodology used is also different. In contrast to the existing literatures studies, Oladeji, Tolulope, Ikpefan \& Olokoyo,(2015) which only examine six out of the listed oil and gas between the year 2003-2012. Whose study identified a negative relationship between capital structure and firm's performance, which means equity, has no potentials to increase returns on the listed firms if sought for. The result is supported by early findings in Nigeria Apkarhuere, Eze \& Unah (2015) the variables used in the study indicated significant negative relationship.

Table 4 indicates a negative significant relationship between Long term debt and firms financial performance. This implies that any increase in debt lead to decrease on return on asset which is attributed to high interest rate, while sales growth and firm listing hard positive and significant regression. This fianding is consisted with the study of Nwaolisa \& Chijindu, (2016) were it was found that financial structure has negative effect on the profitability of oil and gas firms in Nigeria. This finding is in unison with the proposition of the trade-off theory that financial structure and firm profitability are negatively correlated. The indebtedness of oil and gas firms in Nigeria negatively influenced return on assets and return on capital employed. With the fact that commercial banks make available huge loan to oil and gas firm, their performance in relation to profitability have not been enhanced. This could be so because of some economic and political factors which may contributes to the poor earnings in the firms. Some of those factors could include forces of demand and supply in international market, insecurity and pipeline vandalism which in turns can affect the returns from operational activates of the oil and gas firm

\section{Conclusion and Recommendations}

Features of indebtedness mechanism used in this study on financial performance are significant. This study determined empirically the impact of indebtedness on financial performance of quoted downstream Nigeria oil and gas companies from 2007 to 2019. Financial data from 11 listed oil and 
INTERNATIONAL JOURNAL OF ACADEMIC RESEARCH IN ACCOUNTING, FINANCE AND MANAGEMENT SCIENCES

Vol. 10, No. 4, 2021, E-ISSN: 2225-8329 @ 2021 HRMARS

gas firms on Nigeria stock exchange were analyses using explanatory research design. The results of the estimation revealed that indebtedness has negative impact on profitability of oil and gas firms' measure by return on asset and return on capital employed. The finding is in line with previous empirical studies on the existence of negative relationship between indebtedness and firm's profitability. It also provide credence to the Trade-off theory of indebtedness which states that firm should select an optimal capital structure that maximizes the firms value by minimizing cost of prevailing market imperfections Sheikh \& Wang, (2010). Furthermore, firms should determine their preferred sources of leverage by looking at the advantages and disadvantages of the tax shield coupled with the financial distress which include direct and indirect costs from bankruptcy. The study recommends that listed downstream oil and gas firms in Nigeria should reduce use of long term debts to enhance their capital employed with a view to generating more return on investment to cover cost of capital and increase their retained earnings, use more equity capital to finance their activities, borrowing from commercial banks, financial markets and other sources of external financing should be minimize due to high interest rates associated with such facilities. Finally, oil and gas companies should strive as much as possible to reach a compromise between using different sources of debt that will result into highest return

\section{Reference}

Akparhuere, G. O., Eze, N. T., \& Unah, N. A. (2015). Effect of capital structure on retained earnings in the oil and gas sector-Evidence from Nigeria. Issues in Business Management and Economics, 3, 10, 120-132. Http://dx.doi.org/10.15739/IBME.2015.005

Abubakar, A. \& Garba, A. (2019). Financial leverage and financial performance of quoted service firms in Nigeria. Nigeria Journal of Management Technology and Development, 8, 2, 273-282

Chang, C. C., Batmunkh, M. U., Wong, W.k., \& Jargalsaikhan, M. (2019). Relationship between capital structure and profitability: Evidence from four Asian tigers. Journal of Management Information and Decision Sciences, 22, 2, 54-65

Gichuru, D. B., Kung'u, J. M., \& Gakobo, T. W. (2019). Influence of capital structure on profitability of government based deposit taking savings and co-operatives in Kenya. European Journal of Economic and Financial Research, 3, 5, 21-35. doi:10.5281/zenodo.3491158

Harelimana, J. B. (2017). Effect of debt financing on business performance: a comparative study between I \& M bank and bank of Kigali, Rwanda. Global Journal of Management and Business Research, 17, 11, 36-43. http://creativecommons.org/licenses/by-nc/3.0/

Gadzo, S. G., \& Asiamah, S. K. (2018). Assessment of the relationship between leverage and performance: an empirical study of unlisted banks in Ghana. Journal of Economics and International Finance, 10, 10, 123-133. doi:10.58797/JEIF2018.0920

Igbinovia, E. L., \& Ogbeide, D. O. (2019). Capital structure and firm value of selected quoted manufacturing firms in Nigeria. Dutse Journal of Economic Development Studies (DUJEDS), 7, 2, 66-77. www.researchgate..net/publication/334469792

Ikapel, O. F.,. \& Kajirwa, I. H. (2017). Analysis of long term debt and financial performance of state owned sugar firms in Kenya. International Journal of Commerce and Management Research, 3, 2, 108-11. www.mamagejournal.com

Joseph, J. (2018). The leverage effect on financial performance: A Review of Empirical Evidence. https://www.grin.com/document/429684 
INTERNATIONAL JOURNAL OF ACADEMIC RESEARCH IN ACCOUNTING, FINANCE AND

MANAGEMENT SCIENCES

Vol. 10, No. 4, 2021, E-ISSN: 2225-8329 @ 2021 HRMARS

Jeleel, A., \& Olayiwwwwwola, B. (2017). Effect of leverage on firm performance in Nigeria: a case of listed chemicals and paints firms in Nigeria. Global Journal of Management and Business Research: Accounting and Auditing, 17, 2, 16-24. http://creativecommons.org/licenses/by-nc/3.0/

Kenn-Ndubuisi, J. I., \& Nweke, C. J. (2019). Financial leverage and firm financial performance in Nigeria: A panel data analysis approach. Global Journal of Management and Business Research, 9, 4, 13-19.

Kenn-Ndubuisi, J. I., Ifechi, J., \& Onyema, J. (2018). Financial leverage and asset growth: evidence from non-financial firms in Nigeria. Journal of Finance Marketing, 2, 4, 10-15. http://www.alliedadacademies.org/journal-finance-marketing

Lenka, S. (2017). The relationship between company returns and leverage depending on the business sector: empirical evidence from the Czech Republic. Journal of $\quad$ Competitiveness, 9, 3, 98110. doi:10.744/joc2017.03.07

Muchiri, M. J., Muturi, W. M., \& Ngunmi, P. M. (2016). Relationship between financial structure and financial performance of firms listed at east Africa securities exchange. Journal of Emerging Issues in Economics, Finance and Banking (JEIEFB), 5, 1, 1734- 1755. ww.globalbizresearch.org

MacCarthy, J., \& Ahulu, H. (2019). Does capital structure affects firms' performance in Ghana? Panel data analysis. Accounting and finance research, 8, 4, 131-143. doi:10.5430/afr.v8n4p131

Nwaolisa, E. F., \& Chijindu, A. A. (2016). The influence of financial structure on profitability with special reference to Oil and Gas firms in Nigeria. Advance Research, $7,11,1-17$. doi:10.9734/AIR/2016/24568

Nzaripour, M., \& Shadi, H. (2015). Impact of debt financing and effective debt management on performance assessment in Tehran stock exchange. Mediterranean Journal of Social Science, 6, 6, 101-108

Oke, M. O., \& Obalade, A. A. (2015). Testing the validity of optimal capital structure theory in Nigeria listed oil firms. International Journal of Economics, Commerce and Management, 3, 3. http://ijecm.co.uk/

Omollo, B. A., Muturi, W. M., \& Wanjare, J. (2018). Effect of debt financing options on financial performance of firms listed at the Nairobi securities exchange, Kenya. Research Journal of finance and accounting, 9, 10, 150-164. www.iiste.org

Pandey, K. D., \& Sahu, T. N. (2019). Debt financing, agency cost and firm performance: evidence from Indian. Sage, 23, 3, 267-274. doi:10.177/0972262919859203

Prempeh, K. B., \& Sekyere, A. M., \& Asare, E.N. (2016). The effect of debt policy on firm's performance; empirical evidence from listed manufacturing companies on the Ghana stock exchange. Munich Personal RePEC Archive. https://mpra.ub.unimuenchen.de/75200/

Schicks, J. (2014) Over-indebtedness in Microfinance-an empirical analysis of related factors on the borrower level. World Development, 54, 301-324.

Tauseef, S., Lohano, H. D., \& Khan, S. A. (2015). Effect of debt financing on corporate financial performance: evidence from textile firms in Pakistan. Pakistan Business Review. 903-916 
INTERNATIONAL JOURNAL OF ACADEMIC RESEARCH IN ACCOUNTING, FINANCE AND MANAGEMENT SCIENCES

Vol. 10, No. 4, 2021, E-ISSN: 2225-8329 @ 2021 HRMARS

Zaidi, N. S. B., Jais, M. B., \& Karim, B. B. (2019). The influence of debt financing on firms' performance: a study of consumer product industry in Malaysia. International Journal of Academic Research in Business and social sciences, 9, 9, 578-589. www.hrmars.com 